\title{
RESISTIVITY (DC) METHOD APPLIED TO AQUIFER PROTECTION STUDIES
}

\author{
Antonio Celso de Oliveira Braga ${ }^{1}$, Walter Malagutti Filho² and João C. Dourado ${ }^{3}$ \\ Recebido em 4 setembro, 2006 / Aceito em 24 novembro, 2006 \\ Received on September 4, 2006 / Accepted on November 24, 2006
}

\begin{abstract}
Resistivity (DC) method using vertical electrical soundings (Schlumberger array) are conducted in the vicinity of Canoas/RS, applied to environmental studies with the objective of investigating groundwater conditions. The present paper shows a geoelectrical identification of the lithology and an estimate of the relationship between the resistivity and Dar Zarrouk parameters (transverse unit resistance and longitudinal unit conductance) with the properties such as aquifer transmissivity and protection of ground water resources. In the saturated sediments, resistivity values defined the following sequence: clay layers (resistivity $<40$ ohm-m) and sand layers (resistivity $\geq 40 \mathrm{ohm}-\mathrm{m}$ ). Two sand layers were identified; one corresponding to the unconfined aquifer and another to the confined aquifer between two clay layers. In the map of the transverse unit resistance of the unconfined aquifer, the tendencies of high values can be associated with the zones of high transmissivity; hence, these zones are suggested for the installation of monitoring wells. The map of longitudinal conductance illustrates the impermeability of the confining clay layer. Values of $S>1.0$ siemens would indicate zones in which the confined aquifer would be protected; in comparison, values of $S<1.0$ siemens would indicate zones of probable risks of contamination.
\end{abstract}

Keywords: Resistivity, Dar Zarrouk Parameters, Aquifer Protection.

RESUMO. Ensaios pelo método da eletrorresistividade, técnica de campo da sondagem elétrica vertical (Schlumberger array) foram executados no município de Canoas/RS. Esses ensaios tiveram como objetivo principal obter um diagnóstico do lençol freático em áreas de Refinaria - REFAP/PETROBRAS. Este trabalho apresenta uma identificação geoelétrica da litologia e uma estimativa da relação entre a resistividade e parâmetros de Dar Zarrouk (resistência transversal unitária e condutância Iongitudinal unitária) com as propriedades transmissividade e proteção frente a contaminantes dos aqüiferos. Nos sedimentos saturados, os valores de resistividade definiram a seguinte litologia: camadas argilosas (resistividade $<40 \mathrm{ohm}-\mathrm{m}$ ) e camadas arenosas (resistividade $>40 \mathrm{ohm}-\mathrm{m}$ ). Foram identificadas duas camadas arenosas; uma correspondendo ao aqǘfero livre e outra ao confinado, limitado entre duas camadas de argila. No mapa da resistência transversal do aqǘfero livre, as tendências de valores altos foram associadas com as zonas de transmissividades altas; as quais são sugeridas para a instalação poços de monitoramento. 0 mapa de condutância longitudinal ilustra a impermeabilidade da camada argilosa sobreposta ao aqǘfero confinado. Valores de $S>1,0$ siemens indicariam zonas nas quais esse aqǘf́ro estaria mais protegido frente a contaminantes; em compensação, valores de $S<1,0$ siemens indicariam zonas de riscos prováveis de contaminação.

Palavras-chave: Resistividade, Parâmetros de Dar Zarrouk, Proteção de Aqüíferos.

\footnotetext{
${ }_{1}^{1}$ São Paulo State University - UNESP, Department of Applied Geology, Av. 24 A, n. 1515 - Cx. Postal 178, 13500-900 Rio Claro, SP, Brasil. Phone: (19) 3526-2819; Fax: (19) 3534-0327 - E-mail: acobraga@rc.unesp.br

2 São Paulo State University - UNESP, Department of Applied Geology, Av. 24 A, n. 1515 - Cx. Postal 178, 13500-900 Rio Claro, SP, Brasil. Phone: (19) 3526-2841; Fax: (19) 3534-0327 - E-mail: malaguti@rc.unesp.br

${ }^{3}$ São Paulo State University - UNESP, Department of Applied Geology, Av. 24 A, n. 1515 - Cx. Postal 178, 13500-900 Rio Claro, SP, Brasil. Phone: (19) 3526-2848; Fax: (19) 3534-0327 - E-mail: jdourado@rc.unesp.br
} 


\section{INTRODUCTION}

This paper describes the results obtained with DC resistivity method using vertical electrical soundings (Schlumberger array), applied to environmental studies related to groundwater. The study was conducted in the Alberto Pasqualini Refinery - REFAP, Petróleo Brasileiro S.A. - PETROBRAS. The refinery is located in the vicinity of Canoas, State of Rio Grande do Sul (Fig. 1), and it occupies an area of 5,448,437 $\mathrm{m}^{2}$. The Sapucaia River at north, which belongs to the hydrographic basin of Sinos river, limits REFAP. The Sinos River is an important source of water supply of Porto Alegre Metropolitan Area (Pedrozo, 1995).

The geophysical surveys were conducted by the Department of Applied Geology of the São Paulo State University - UNESP, Rio Claro, and their main objectives were: (1) to characterize the groundwater, identifying eventual contamination plumes of hydrocarbon (Sauck, 2000; Goes \& Meekes, 2004); and, (2) to help in the characterization of the lithology, helping the hydrogeology studies in the area with the objective of characterizing the information about the water table and the different lithologies presented; evaluating the potential places of contamination of the underground water (Cummings, 1990); and proposing a program for the protection and conservation of the waters.

The technique of the vertical electrical soundings - Schlumberger array, consists of a quite fast and versatile procedure of geophysical investigation. Its results are not highly affected by the operational difficulties imposed in the industrial area of the refinery; which makes the characterization of the local lithology possible. Besides, it is a widely known technique to determine the position of the water table (Braga et al., 1999; Orellana, 1972), whose information is fundamental for the elaboration of the potentiometric surface map.

\section{Geology}

According to CPRM (1997), the area of the city of Canoas is characterized by the existence of three different geological structural provinces, denominated Costeira (Cenozoic sediments), $\mathrm{Pa}$ raná (sediments, basaltic lavas, and diabase sills of the Mesozoic) and Mantiqueira (Palaeozoic rocks), which present very different lithostratigraphy, chronological and geomorphology characteristics. The refinery is located in a zone near the contact between the Costeira and Paraná provinces. In the studied area Quaternary sediments occur (alluviums) with maximum thickness of about 10 meters. Also Triassic sediments of Rosário do Sul Group, appear in the elevated parts of the area, which are represented by Sanga do Cabral Formation, with medium thickness of 40 meters.
Sanga do Cabral Formation is the main geological unit on which the refinery is located, being in part covered by the sediments of recent alluvium, and in part by materials of original embankment of the construction of the refinery. It is composed predominantly of fine to very fine, red sand, with grooved crossed beddings of medium load sandstones. Thicker sandstones with granules and pebbles can appear as well as siltstones and claystone lenses. The depositional environment of that unit is fluvial, fluvial-eolian or predominantly eolian. According to hydrogeological data, this group of geological units characterizes an aquifer system of local importance.

\section{METHOD AND DATA ACQUISITION}

\section{Electrical resistivity method and vertical electrical sounding (VES) technique}

Resistivity (DC) measurements using the technique of the vertical electrical sounding (VES) - Schlumberger array were used in the survey area. To cover in a uniform way the survey area, 120 (a hundred and twenty) VES were conducted (Fig. 2). The Schlumberger array was used with maximum current-electrode separations (AB) of 200 meters. The geophysical equipment used in the field surveys consisted of the standard for Induced Polarization and Resistivity Surveying - Terrameter SAS 4000/ABEM.

\section{Parameters and functions of Dar Zarrouk (DZ)}

In theories about stratified conductors, certain parameters are fundamentally important both in the interpretation and understanding of the geoelectrical model consisting of stratified conductors. These parameters are related to different combinations of the thickness and resistivity of each geoelectrical layer in the model (Zohdy, 1974; Orellana, 1972).

For a sequence of $n$ horizontal, homogeneous and isotropic layers of resistivity $\rho_{i}$ and thickness $h_{i}$, the DZ parameters (Iongitudinal conductance $\mathbf{S}$ and transverse resistance $\mathbf{T}$ ) are defined respectively:

$$
\begin{gathered}
S_{i}=\sum_{i=1}^{n} \frac{h_{i}}{\rho_{i}} \text { (siemens) } \\
\left.T_{i}=\sum_{i=1}^{n} \rho_{i} \cdot h_{i} \text { (ohm. } \mathrm{m}^{2}\right)
\end{gathered}
$$

\section{RESULTS AND ANALYSIS \\ Geoelectrical model}

The quantitative treatment of the vertical electrical soundings provided geoelectrical information characterized by the values of 


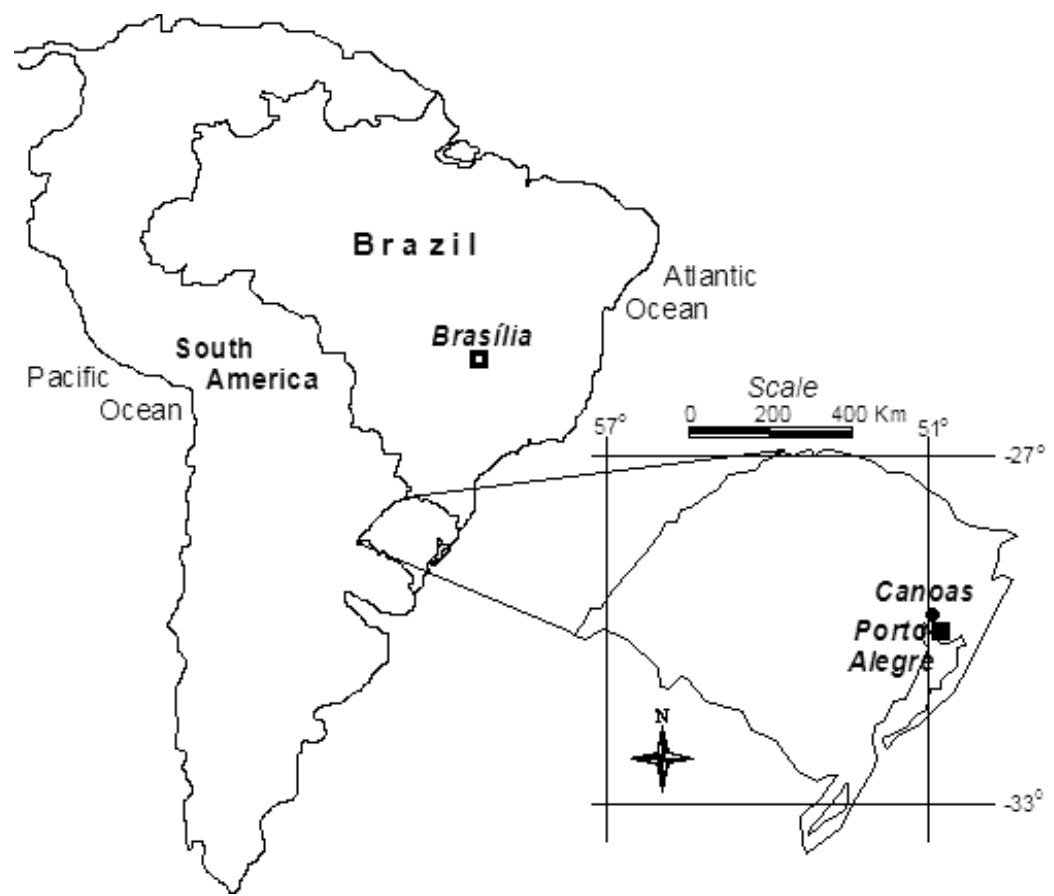

Figure 1 - Location and geological maps of Rio Grande do Sul State (modified from CPRM - 1997).

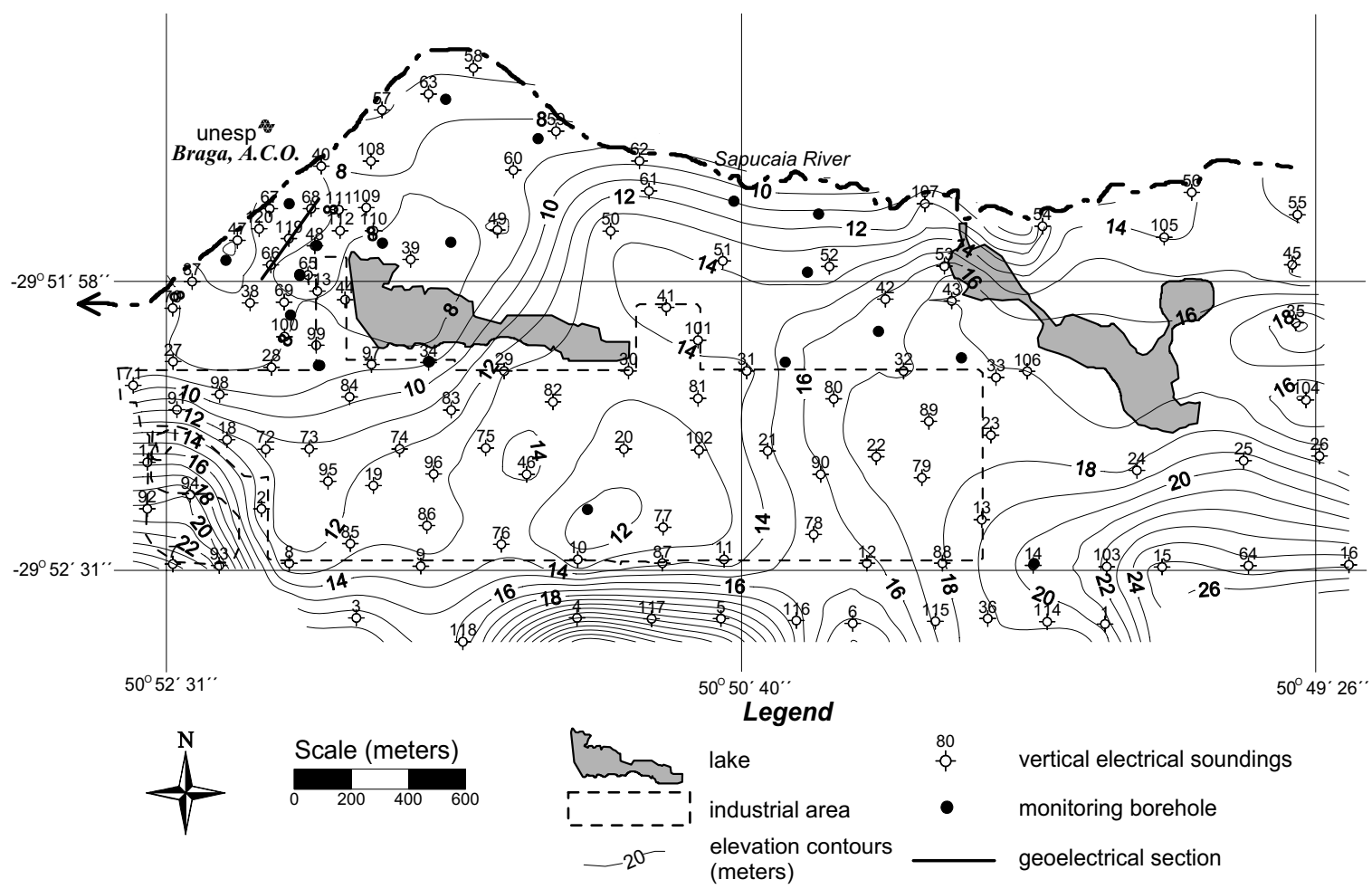

Figure 2 - Topographical map and location of the vertical electrical soundings and monitor wells. 
resistivity and thickness. These geoelectrical parameters defined the geoelectrical model. The inversion of the field data was done using the software RESIX-IP (2002) version 2.00, from Interpex Limited-USA. The obtained error for the final fitting between field data and model using RESIX-IP software (2002) was around 3 to $8 \%$. In order to correlate the geophysical surveys with the geology of the study area, geological data were collected from the surface and sub-surface, and electric surveys of calibration were developed near to the monitoring well (22 wells). The geoelectrical model was determined as a function of the calibration with the data from wells and the resistivity contrast between high and low values.

This interpretation determined the depth to the water level, defining: (1) unsaturated sediments, and (2) saturated sediments. Resistivity values for the unsaturated sediments varied considerably (7 to 1,439 ohm-m), which is typical for unsaturated sediments. Due to this variation in the resistivity values, it is not possible to characterize the lithology in the unsaturated zone. For the saturated sediments, the following sequence can be defined for the locations studied: clay layers (resistivity $<40 \mathrm{ohm}-\mathrm{m}$ ) and sand layers (resistivity $\geq 40 \mathrm{ohm}-\mathrm{m}$ ). As a whole, two sand layers were identified: one corresponding to the unconfined aquifer and another to the confined aquifer, between two clay layers. The Figure 3 shows the geoelectrical section.

\section{Facies variations}

The lithology of the study area and the geological data of the monitoring borehole define a stratigraphic sequence: sand layer-1 (unconfined aquifer); clay layer-1; sand layer-2 (confined aquifer); and, clay layer-2.

Based on the calibration studies of the geoelectrical model with the wells data, facies variations were identified in the sand and clay layers. The Table 1 presents the geoelectrical model, correlated with lithology in terms of prevalence of the material type. The resistivity values between 20 and 60 ohm-m include clay-sand and sand-clay variations.

Table 1 - Geoelectrical model.

\begin{tabular}{|c|c|c|}
\hline & $\begin{array}{c}\text { Lithology } \\
\text { (prevalence) }\end{array}$ & $\begin{array}{c}\text { Resistivity } \\
\text { (ohm-m) }\end{array}$ \\
\hline Unsaturated sediments & uncertain & 7 to 1,440 \\
\hline \multirow{5}{*}{ Saturated sediments } & clay layers & $\rho \leq 20$ \\
& clay-sand layers & $20<\rho<40$ \\
& sand-clay layers & $40 \leq \rho<60$ \\
& sand layers & $\rho \geq 60$ \\
\hline
\end{tabular}

The Figure 4 illustrates a field curve obtained using the VES technique and the geoelectrical model that generates a best fitting model curve, executed beside PM-01 well. It is observed, in this illustration, that the correlation of the geophysical data with the lithology, just happens in the saturated section, determined by the water table. The geoelectrical classification of the material is made in prevalence terms, where the geoelectrical layer, predominantly sandy (210 ohm-m), includes sand-clay and the sand layers.

The Figure 5 illustrates field curves of occurrence and nonoccurrence areas of the unconfined aquifer - sand layer- 1 .

\section{First saturated geoelectrical layer}

With the objective of identifying the lithology of the first saturated geoelectrical layer, located below the water table, which could indicate zones of the underground with larger or smaller capacity of protection to contaminants, a resistivity map was elaborated. This map refers to the geoelectrical level, whose top was determined by the position of the water table, separating the dry portion of the saturated (Fig. 6).

The sand layer-1 (unconfined aquifer) presented larger thickness in the north portion of the studied area, extending to the south and to the portion west. In some isolated locals, the sand-1 level does not appear, presenting the clay- 1 layer underneath the unsaturated sediments.

In the resistivity map (Fig. 6) the values smaller than 40 ohm$\mathrm{m}$ are associated predominantly with clay sediments (clay-sand and clay). The transition from clay to sand is gradual, presenting intermediary layers of clay-sand and sand-clay sediments.

\section{Aquifer protection: sand-1 (unconfined aquifer) and sand-2 (confined aquifer)}

The applications go beyond standard hydrogeological applications of resistivity sounding, which commonly aim at the definition of an aquifer's geometry and lithology. The combination of thickness and resistivity into single variables, the Dar Zarrouk parameters (Maillet, 1947); can be used as a base for the evaluation of properties such as aquifer transmissivity and protection of ground water resources (Henriet, 1975).

Aquifer transmissivity is defined in the hydrogeology, as the product of its hydraulic conductivity for the thickness of the layer. As the hydraulic conductivity is directly proportional to the resistivity (Kelly, 1977) and the product of the resistivity for its thickness, it is defined as being the transverse resistance $(T)$, on a purely empirical basis and it can be admitted that the transmis- 


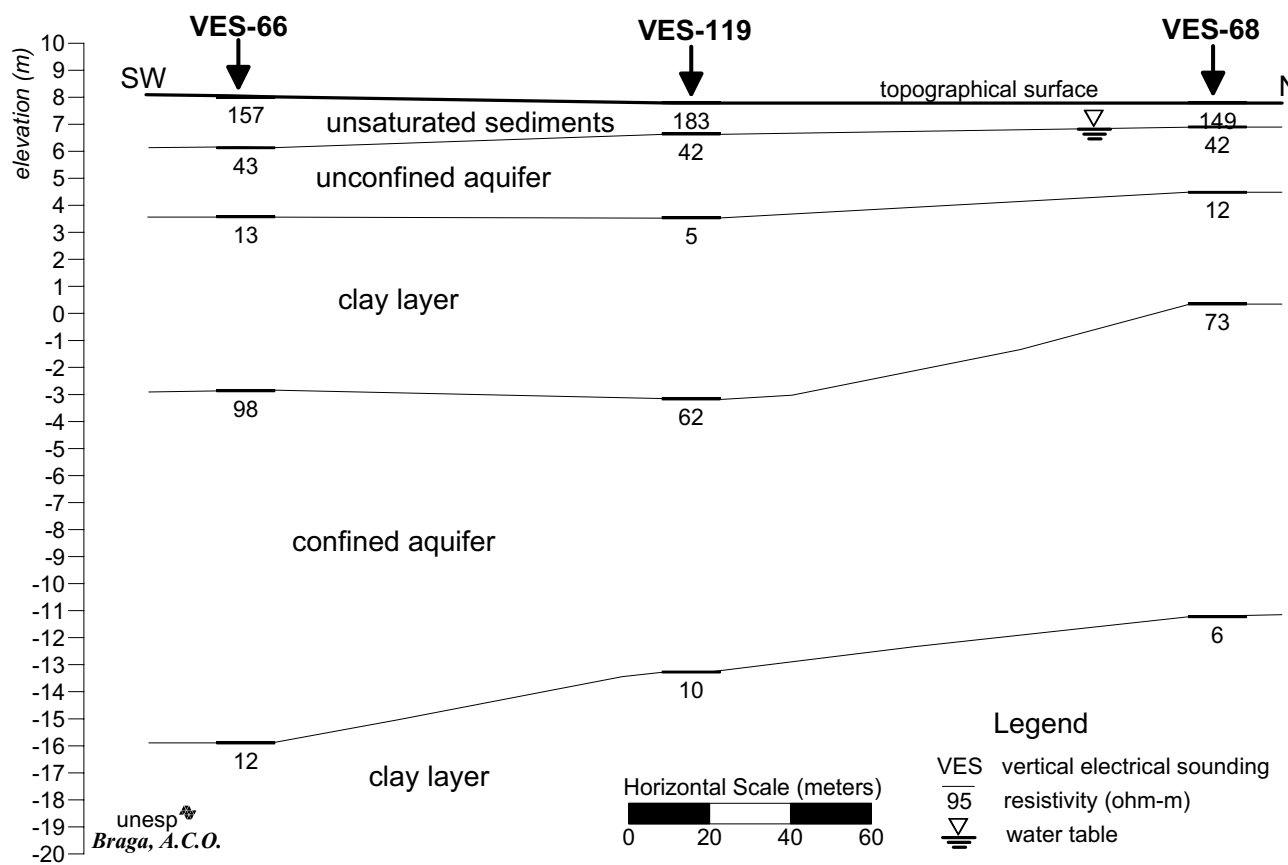

Figure 3 - Geoelectrical section.

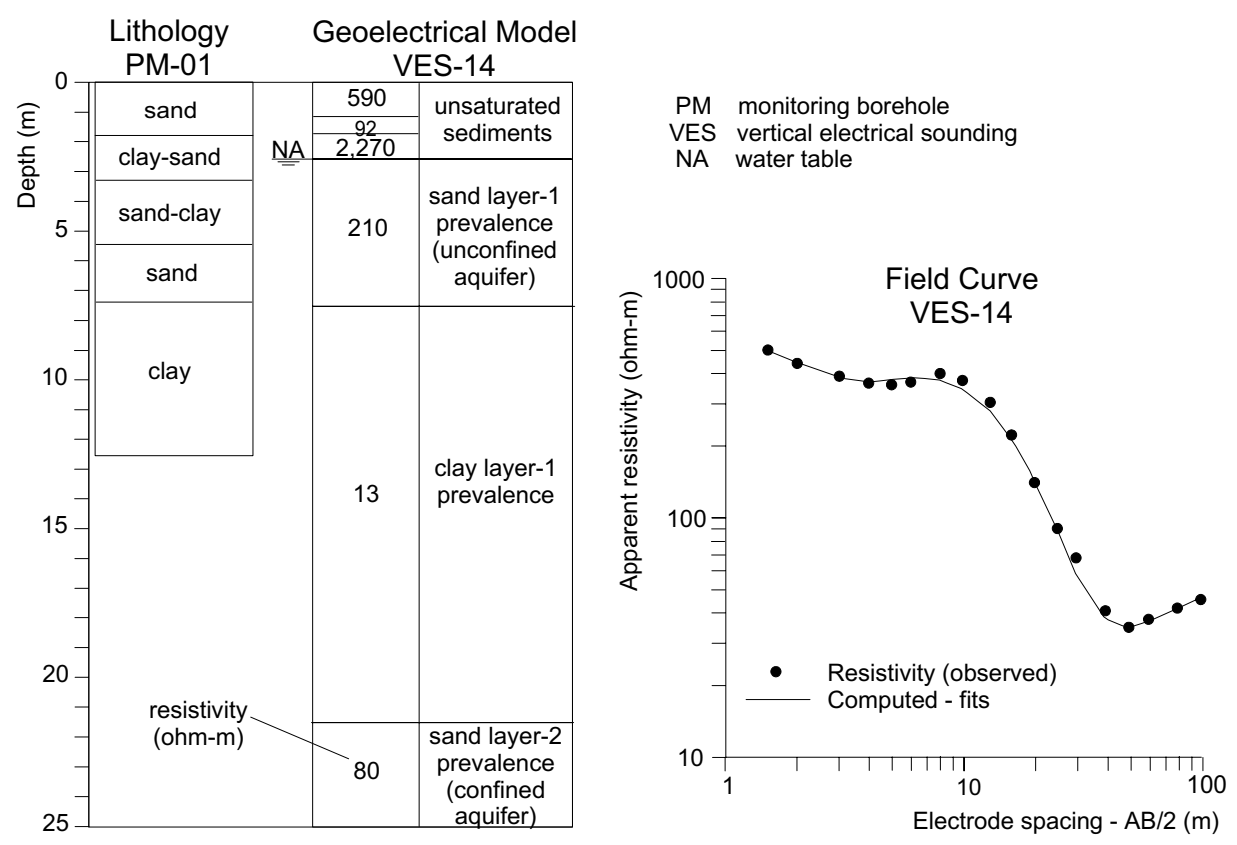

Figure 4 - VES - Example of field curve, geoelectrical model and lithology of the monitoring borehole PM-01.

sivity of an aquifer is directly proportional to its transverse resistance (Henriet, 1975; Ward, 1990). Clay layer corresponds with low resistivities and low hydraulic conductivities, and vice versa, hence, the protective capacity of the overburden could be consi- dered as being proportional to the ratio of thickness to resistivity - longitudinal conductance (S).

The correlation between the resistivity and the hydraulic conductivity can only be considered in clean saturated sediments, 


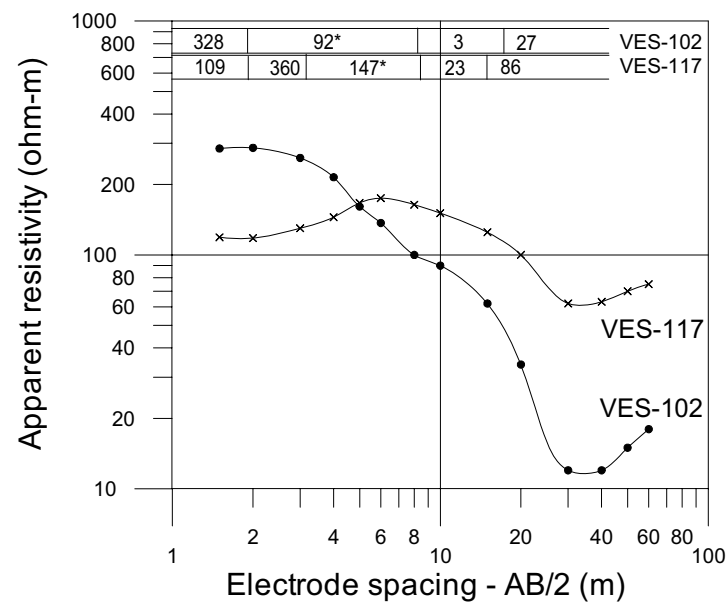

(a) occurrence area of the unconfined aquifer - sand layer-1 $\left(^{*}\right)$

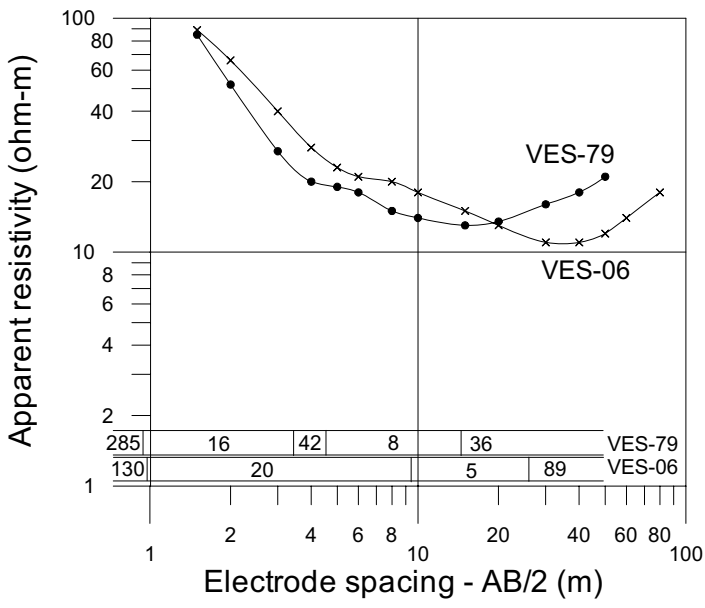

(b) non-occurrence area of the unconfined aquifer - sand layer-1

Figure 5 - VES-Example of field curves.

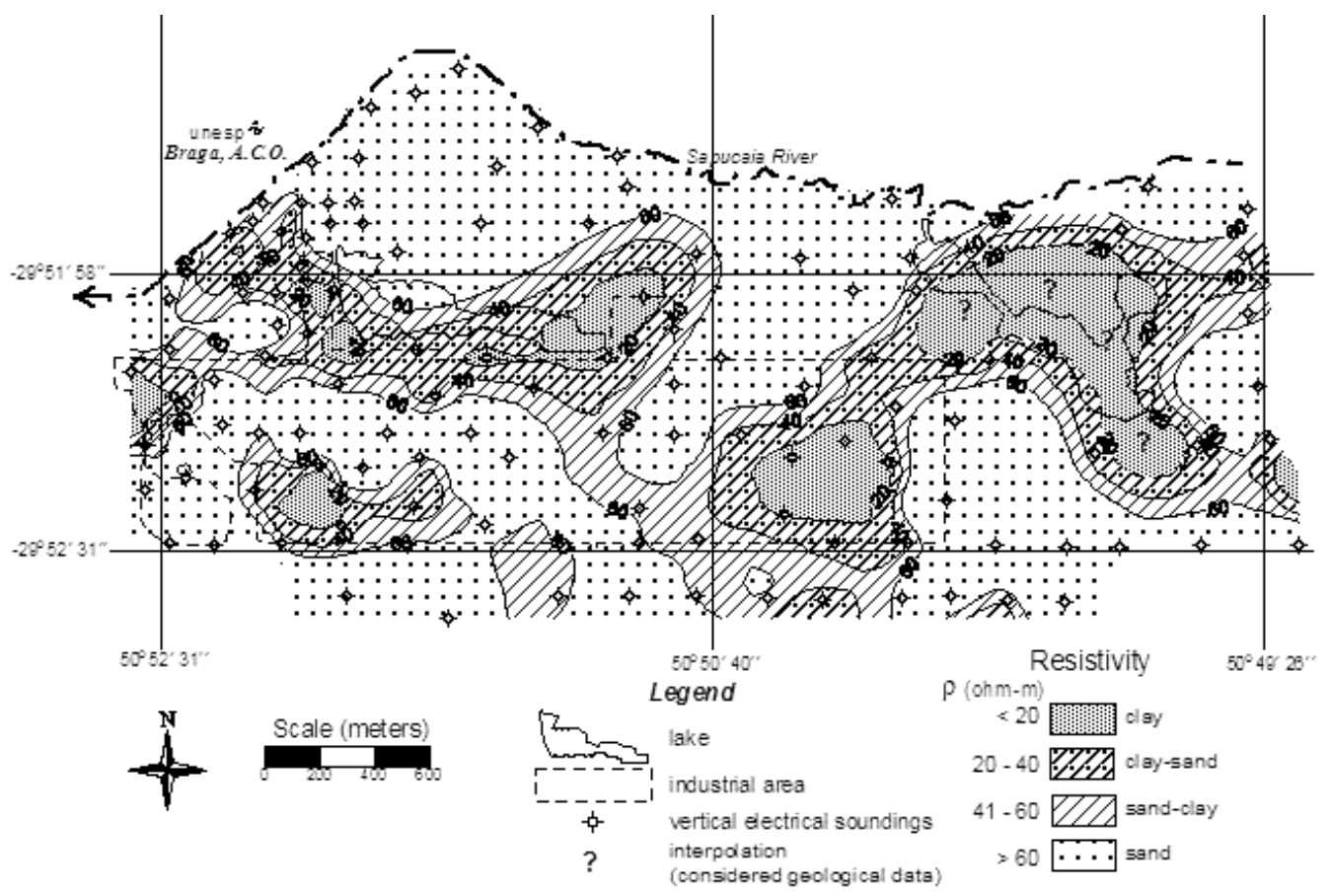

Figure 6 - Resistivity map - first saturated layer.

whose natural fluids characteristics are considered constant. In areas where the sediments can be contaminated, with, for instance, hydrocarbon derived, this correlation is not valid.

The Figure 7 illustrates the map of $T$ of the sand layer- 1 (unconfined aquifer). In this map, the tendencies of high values of $T$ $\left(>400\right.$ ohm- $\mathrm{m}^{2}$ ) can be associated with zones of high transmis- sivity; hence, these zones are indicated for installation of monitoring wells for the unconfined aquifer.

The map of longitudinal conductance (Fig. 8) illustrates the protective capacity of the overburden layer (clay-1) on the confined aquifer (sand-2). In this illustration, values of $S>1.0$ siemens would indicate zones in which the confined aquifer would 


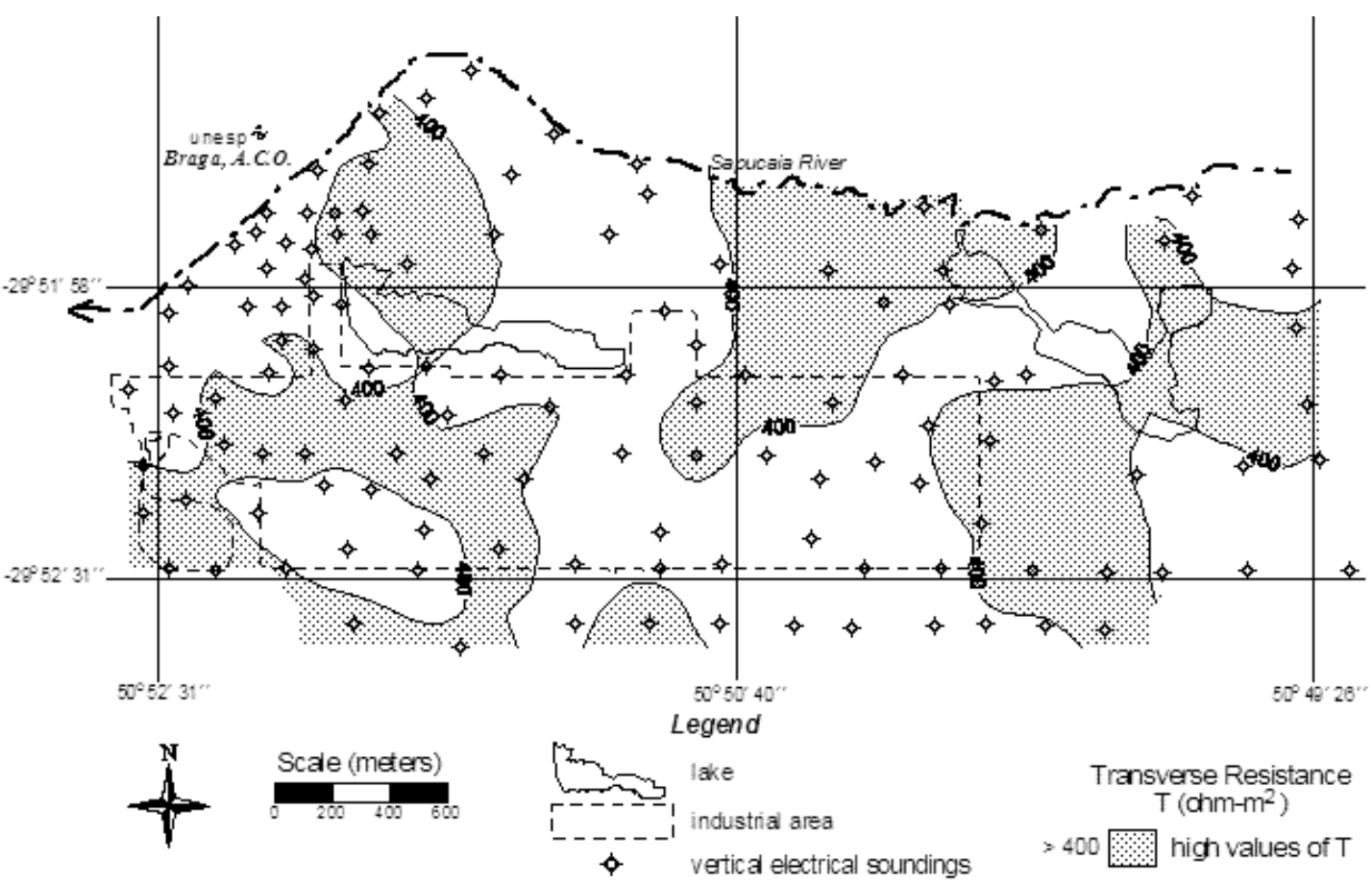

Figure 7 - Transverse resistance map - sand 1 (unconfined aquifer).

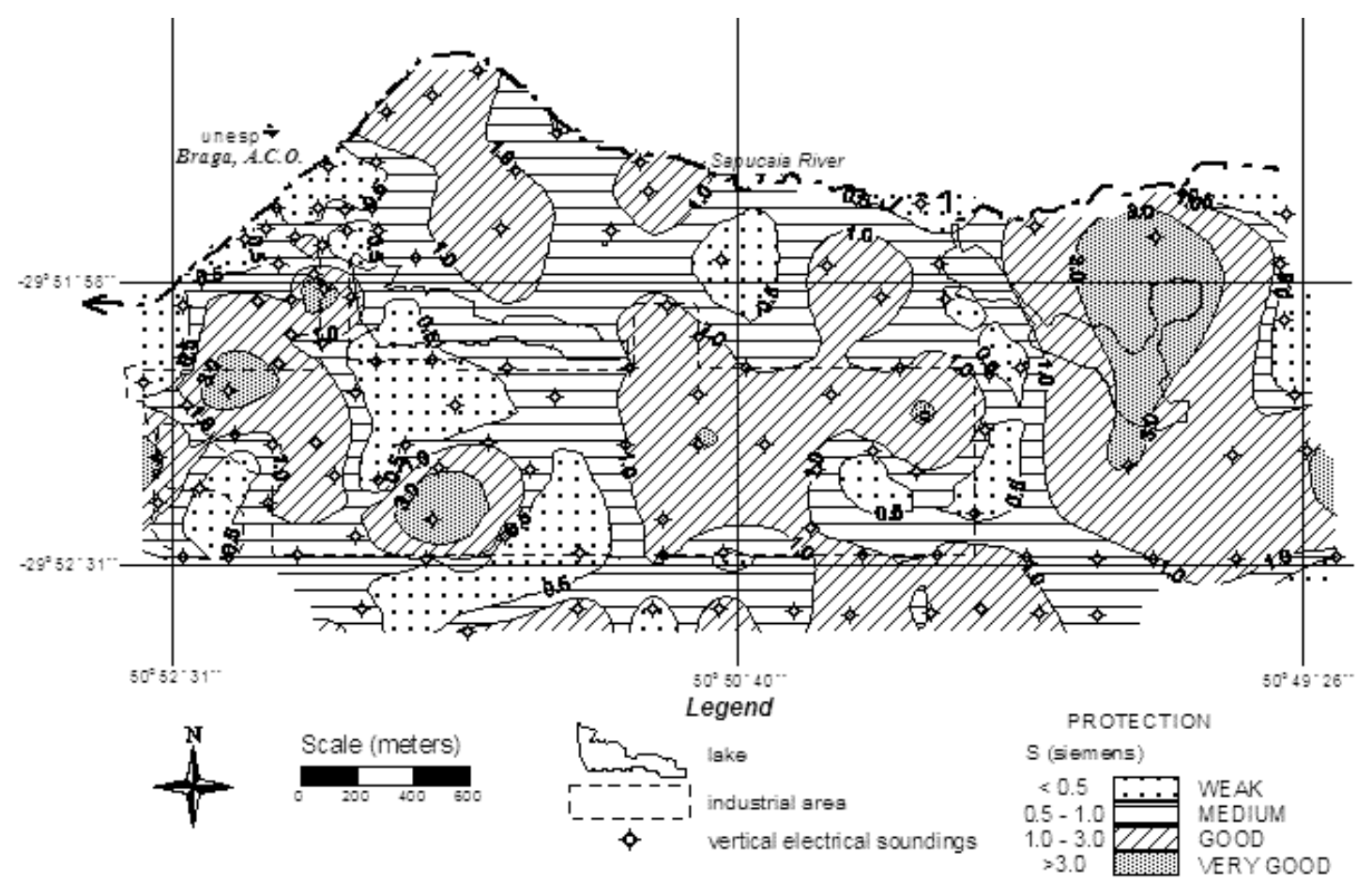

Figure 8 - Longitudinal conductance map - clay-1. 


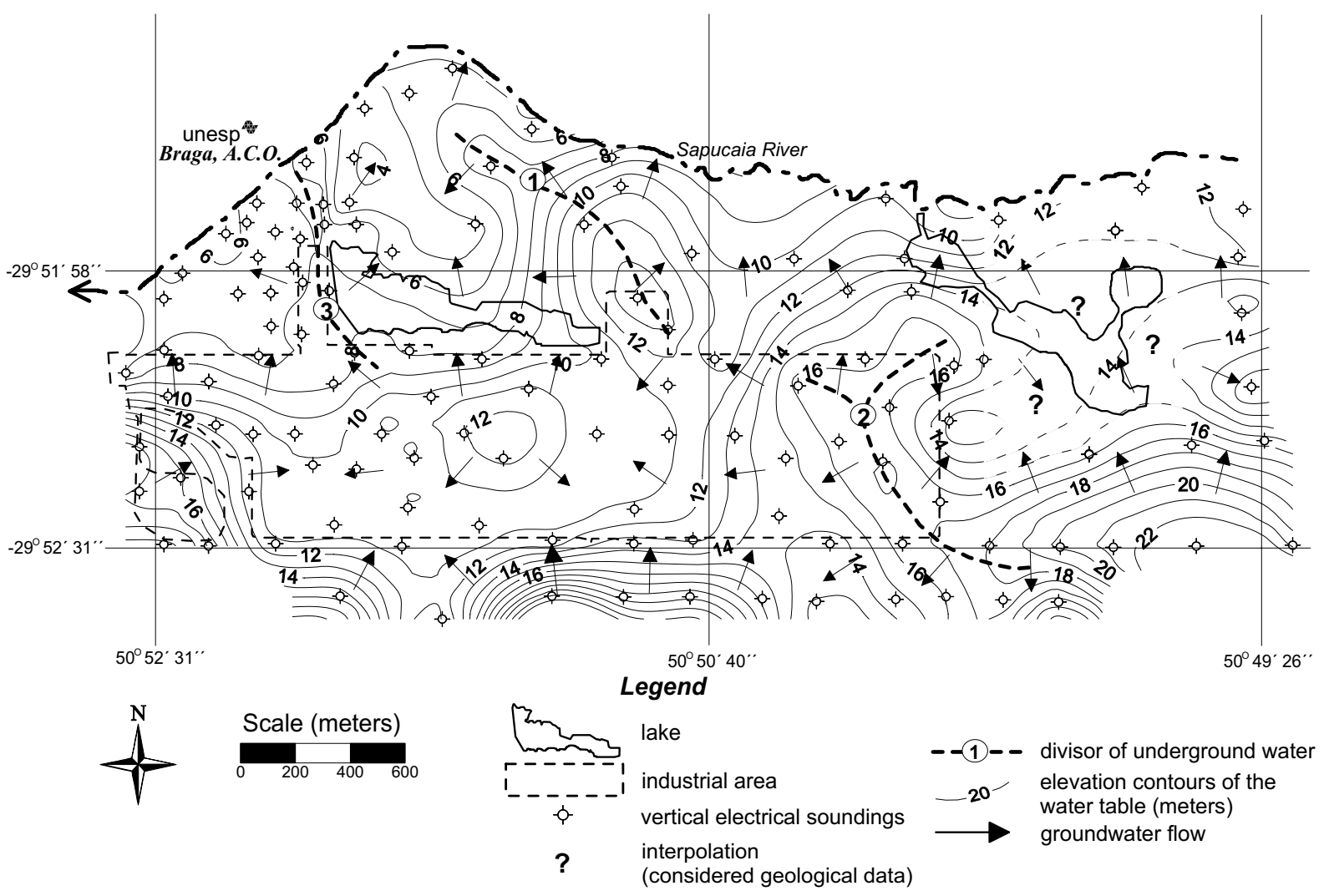

Figure 9 - Potentiometric surface map - unconfined aquifer.

be protected. In comparison, values of $S<1.0$ siemens would indicate zones of probable risks of contamination.

\section{Potentiometric-surface map}

The values of the elevation of the water table - unconfined aquifer, determined for each VES, allowed the plan of the potentiometric map (Fig. 9). This map, besides establishing the pattern of the underground flow, allows determining the groundwater divides and the fundamental data for the environmental studies aiding in the installation of the monitoring wells.

It can be observed in Fig. 9, that the regional tendency of the underground flow is towards river Sapucaia - flushed zone. Inside of this regional tendency, there are two preferential roads of the flow, making corridors with NW directions approximately.

Locally, variations as to this regional flow can be observed. These variations happen because of directional changes of groundwater flow, associated with the occurrence of a superficial clay layer.

\section{CONCLUSIONS}

The geophysical survey allowed us to obtain lithological identification and to characterize the conditions of the underground flow of the studied area. Two sand layers were identified; one corresponding to the unconfined aquifer and another to the confined aquifer between two clay layers. A map of the transverse unit resistance illustrates the unconfined aquifer. In this map, the tendencies of high values of $T$ can be associated with the zones of high transmissivity; hence, these zones are suggested for the installation of monitoring wells for the unconfined aquifer. The map of Iongitudinal conductance illustrates the impermeability of the confining clay layer. Values of $S>1.0$ siemens would indicate zones in which the confined aquifer would be protected; in comparison, values of $S<1.0$ siemens would indicate zones of probable risks of contamination. In the studied area it was not identified eventual contamination plumes of hydrocarbon.

\section{ACKNOWLEDGMENTS}

The authors thank the Foundation for the Development of UNESP and the Department of Applied Geology at São Paulo State Uni- 
versity - UNESP, for contributing with equipment and personnel for this work and Petróleo Brasileiro S.A. - PETROBRAS.

\section{REFERENCES}

BRAGA ACO, MALAGUTTI FILHO W, DOURADO JC \& CHANG HK. 1999. Correlation of electrical resistivity and induced polarization data with geotechnical survey standard penetration test (SPT) measurements. Journal of Environmental and Engineering Geophysics (JEEG) - The Environmental and Engineering Geophysical Society (EEGS), 4(2): 123-130.

CPRM. SERVIÇO GEOLÓGICO DO BRASIL. 1997. Tectono-Geological Map of Brazil, 1:20,000,000. Disponível em:

<http://www.geoambiente.com.br/data/cprm/LEIAME_brasil.htm>. Acesso em: 20 mar. 2003

CUMMINGS D. 1990. Surface geophysical investigations for Hazardous Waste Sites. Geophysical Applications for Geotechnical Investigations, ASTM STP 1101, FREDERICK LP \& WAYNE RS (Ed.), American Society for Testing and Materials, Philadelphia, p. 9-16.

GOES BJM \& MEEKES JAC. 2004. An effective electrode configuration for detection of DNAPLs with electrical resistivity tomography. Journal of Environmental \& Engineering Geophysics, 9(3): 127-141.

HENRIET JP. 1975. Direct applications of the Dar Zarrouk parameters in ground water surveys. Geophysical Prospecting, 24: 344-353.
KELLY WE. 1977. Geoelectric sounding for estimating aquifer hydraulic conductivity. Ground Water, 15(6): 420-425.

MAILLET R. 1947. The fundamental equations of electrical prospecting. Geophysics, 12(4): 529-556.

ORELLANA E. 1972. Prospección geoeléctrica en corriente continua. Madrid, Ed. Paraninfo, Biblioteca Técnica Philips, 523 p.

PEDROZO CS. 1995. Test of toxicity of effluents of the Alberto Pasqualini Refinery. M.Sc. Dissertation, Pontifícia Universidade Católica, Porto Alegre, $95 \mathrm{p}$.

SAUCK WA. 2000. A model for the structure of LNAPL plumes and their environs in sandy sediments. Journal of Applied Geophysics 44: 151-165.

RESIX-IP SOFTWARE. 2002. Version 2.00 - 1D Sounding Inversion Interpex Limited. Colorado/USA.

WARD SH. 1990. Resistivity and induced polarization methods. USA. Investigations in Geophysics, no 5. Geotechnical and Environmental Geophysics. Society of Exploration Geophysicists, WARD SH. (Ed.), I: 147-189.

ZOHDY AAR. 1974. Use of Dar Zarrouk curves in the interpretation of vertical electrical sounding data. United States Geological Survey Bulletin $1313-\mathrm{D}, 41 \mathrm{p}$.

\section{NOTES ABOUT THE AUTHORS}

Antonio Celso de Oliveira Braga received his B.S. degree in geology (1978) and his Ph.D. degree in Geosciences and Livre-docente from the São Paulo State University (UNESP), Brazil. He worked with applied geophysics in Institute for Technological Research of the State of São Paulo - IPT (1978 to 1995). He was a visiting Professor at Institute of Astronomy and Geophysics (IAG) at University of São Paulo (USP), Brazil (1987 to 1989). He is professor of geology at São Paulo State University (UNESP). He works in the application of geophysical methods to environmental problems, hydrogeology and engineering geology. Research has included applications of electrical resistivity, potential and induced polarization methods.

Walter Malagutti Filho is professor of applied geophysics at the São Paulo State University (UNESP). Prior to joining UNESP in 1986, he worked at the Institute for Technological Research of the São Paulo State (IPT) from 1981 to 1986 in the applied geophysics group. He received his B.S. degree in geology and PhD degree and Livre-docente from São Paulo State University. He works in the application of geophysical methods to environmental problems, hydrogeology and engineering geology. Research has included applications of electrical resistivity, induced polarization, seismic, GPR and potential methods.

João Carlos Dourado received his B.S. in geology from University of São Paulo (USP) in 1977 and Ph.D. degree (1997) in Geosciences and Livre-docente from the São Paulo State University (UNESP), Brazil. He worked with applied geophysics in Institute for Technological Research of the State of São Paulo - IPT (1977 to 1997). From 1987 to 1989 he was a visiting professor at Institute of Astronomy and Geophysics (IAG) from the University of São Paulo (USP). Currently he is an professor of geology at São Paulo State University (UNESP). He works in the application of geophysical methods. Professional interests: Near-surface seismic, radar imaging, processing and instrumentation. 